\title{
Modeling the Factors that Influence Employee Attitude and Service Delivery Behavior among Higher Education Professionals
}

\author{
*Omoruyi O., Chinomona E \\ Vaal University of Technology, South Africa \\ chakubvae@hotmail.com
}

\begin{abstract}
Good and well calculated service delivery is very essential for the smooth running of institutions and for life long learning of students. Looking at factors that lead to employee attitude and service delivery bevaviour helps the higher education professionals to build a strong positive relationships with peers, students, staff and university leaders. This paper will look at remuneration, professional development and Information Communication Technology (ICT) efficiency as factors that contribute to positive employee attitude and good service delivery behaviour. Efforts by higher education institutions to improve the quality and standards of education professionals have progressed through the use of various forms of student feedback and methods of evaluation in an attempt to understand what matters to students' and educational professionals regarding their educational experience. Structured questionnaires were distributed to university professionals, which include all university staff like Deans of faculties, Heads of departments and lecturers at one University of Technology (UoT). A quantitative method using Smart PLS was employed to test the relationships among the four hypotheses. The positive relationship between the four proposed hypotheses validatesthat remuneration; professional Development and ICT efficiencyare instrumental strategy to stimulating employee attitude and service delivery behavior of employees.Practically, the study build on a new direction towards research based on consumer behaviour by opening up a discussion on the importance of marketing practices in the development and improvement of service delivery behaviours in one UoTs in South Africa. Based on the findings, recommendations will be made to both the university policy makers and the university professionals for efficacy reasons. The proposed study is expected to have practical and theoretical implications to policy makers for the university and university professionals. In addition, it will provide added insights and added new knowledge to the existing body of literature hitherto not studied extensively in South Africa and UoT in particular.
\end{abstract}

Keywords: Equity theory, Remuneration, Professional development, Information communication technology efficiency, Employee attitude, Service delivery behaviour

\section{Introduction}

Positive service delivery behaviour of employees is crucial in any service organisation as it connects the organisation with its customers, thereby representing a critical factor towards the development of effective customer working relationships (Doherty, Shakur \& Ellis-Chadwick, 2015, Andrzejewski \& Mooney, 2016). Service delivery behaviour can also serve to maintain customer satisfaction by fulfilling the promises made to customers. However, for the delivery behaviour to have a positive effect on services rendered, it should be nurtured by the application of specialised competencies and expertise for the benefit of the organisation and its clients (Pugh \& Subramony, 2016). Therefore, delivery behavior necessitates obligatory pre-requisites such as training and development, ICT efficiency and remuneration, for it to produce value among stakeholders. Service delivery behavior among higher education professionals is essential for quality performance, development and continued existence of institutions of learning (Nisiforou, Poullis, \& Charalambides, 2012, Sá, Rocha, \& Cota, 2016). The significance of service delivery has been widely acknowledge as a mechanism for success, development, customer retention and relationship and sustainability especially among the public and private service sector in South Africa (Lues, 2007; Dorasamy, 2010; Sibanda, 2012). Service delivery behavior has the potential of enhancing organization's well-being and competitive performance which may further enhance service quality. According to Bienstock, DeMoranville and Smith, "the lifeblood of a service organization is its employees". Therefore, an acceptable standard of service delivery behavior is very essential. Due to its importance, strategies and tools such as organizational 
citizenship behavior (OCB), customer orientation behavior (COB) and etc. has been put in place to ensure efficient and effective enhancement of employee attitude towards service delivery behavior (Lin \& Lin, 2011; Mechinda \& Patterson, 2011; Jain, 2015; Zayas-Ortiz, Rosario, Marquez, \& Gruneiro, 2015; Wen, Li \& Hon, 2016; Chumg, Seaton, Cook \& Ding, 2016). Its influence within any service organization culminates in either positive or negative reputation (Echchakoui, 2016); accomplished or unaccomplished goals as well as commitment or lack of commitment, thereof (Ratanavaraha, Jomnonkwao, Khampirat, Watthanaklang, \& Iamtrakul, 2016, Verbich, \& Ahmed, 2016). In order words, service delivery behavior can hinder positively or negatively on organization's reputation as well as organization's promise made to customers.

Broadly, service delivery can be defined as deeds, performances and efforts that cannot physically be possessed (Pugh \& Subramony, 2016). Service delivery is both the mechanical and human effort of providing a service to satisfy customer specific needs (Wang, Zhao, \&Voss, 2016). According to Holtom, and Burch (2016), Pugh and Subramony (2016), service delivery may be characterized as intangible (cannot be touched), inseparable (production and consumption happen at the same time) and heterogeneous (unrelated) in nature. In this case the customer or client may either find increased value and satisfaction or loss value and dissatisfaction as a result of negative service delivery behavior (Mpofu \& Hlatywayo, 2015). Therefore Higher Education as a service organization should strive to ensure that service behavior by an individual professional brings satisfaction, customer benefits and good performance. Higher Education professionals in the field of marketing and management precisely, have researched on service delivery behavior impact on satisfaction and mostly focusing on service delivery processes in creating service quality performance (Mpofu \& Hlatywayo, 2015, Holtom, \& Burch, 2016, Wahab, Bentahar, Otrok, \& Mourad, 2016, Liu \& Lee, 2016). However, according to this study, service delivery process may not have a direct influence on service delivery behavior as proposed by previous researchers without first dealing with determinants of employee attitude toward a change in service delivery behavior (Bartel, Freeman, Ichniowski \& Kleiner, 2011). For this study therefore, service delivery behavior is the outcome of interface between higher education integrated processes and teaching professionals that can be influence by some input factors such as remuneration, continuous development or training and institution ICT efficiency (Thomas, Passfield, Coulton, \& Crone 2016, Mpofu, \& Hlatywayo, 2015). The above mentioned factors can positively influence employee attitude towards positive service behavior improvement and productivity. Modeling the factors that influence employee working attitude and service delivery behavior among higher education professionals is the focus of this study. The proposed framework for this study examine employee working attitude as the mediating variable between the determinants of the service delivery behavior among the South Africa higher education professionals in UoT, particularly in Gauteng Province.

Figure 1: Proposed research model

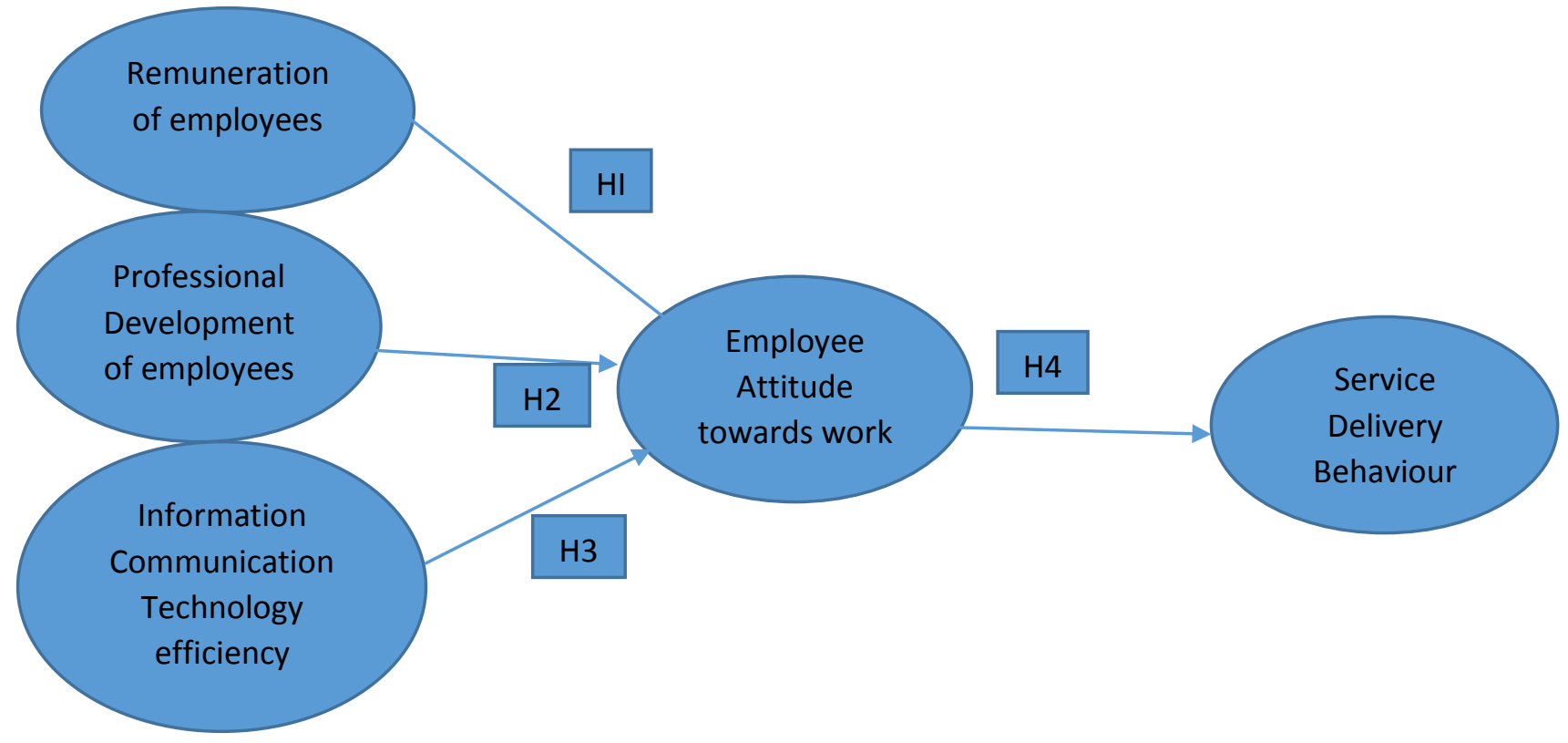




\section{Literature Review}

Equity theory: Equity theory which originated from the discipline of psychology is based on cognitive dissonance theory which was developed by Festinger in the 1950s (Kinicki \& Kreitner, 2008). The equity theory is a model of motivation that explains how people strive for fairness and justice in social exchanges or give-and-take relationships. Researchers have demonstrated that people attempt to "get even" for perceived injustices by using either direct responses such as theft, sabotage, violence or absenteeism or indirect responses such as being less cooperative and displaying low levels of organizational service delivery behavior (Ang, Van Dyke \& Begley, 2003; Almar, 2005). Adams (1963; 1965) who pioneered the application of the equity principle to the workplace, established that the relationship of individual organization exchange is pivotal in the formation of employees' perceptions of equity and inequity because workers expect an organization to be fair and reciprocate by working harder. The equity theory theorized that some people become very upset over the slightest inequity whereas others are not disturbed at all. Research has shown that people respond differently to the same level of inequity due to individual difference called equity sensitivity (Steinbeis \& Singer, 2013). When relating the Equity theory to this study it is assumed that the employees in one UoT may experience distress or poor service delivery behavior, if for example, they expect the ratio between effort spent and rewards received at work to be inequitable when compared to the average contribution of others. As a result of this perception of inequity, the workers are likely to behave in a way to avoid this distress by reducing among others, their commitment to the employer, bad employee attitude or vice versa. If higher education professionals are given fair remuneration, good and up to date professional development will result in a positive employee attitude and positive service delivery behavior.

Determinants of service delivery behavior: The delivery of improved service quality among tertiary institutions in South Africa has been and continues to draw attention from the external and internal environment. There are various factors that affect service delivery and it is the purpose of the study to analyze those factors and come up with recommendations on how to improve service delivery.

Remuneration and employee attitude: Employee compensation in the form of remuneration or salary is another important factor that determines service delivery behavior in this study. Remuneration can bring about positive employee attitude to delivering value and goal achiever if the employee is satisfied (Davies, Taylor \& Savery, 2001, Chaiprasit \& Santidhirakul, 2011, Antoncic \& Antoncic, 2011). According to Aguinis, Joo and Gottfredson (2013) and Wells (2015), well paid employees are motivated to work with positive attitude towards clients and easily become adapted to skill development, organizational goals, performance and profitability. Remuneration increases teaching professionals' level of commitment/engagement and involvement towards organizational goals and its values (Hon, 2012, Anitha, 2014, Blašková \& Blaško, 2014). According to Carraher (2011) and Zalewska (2014), monetary remuneration is a major cost factor of production that an employer uses to attract/retain, motivate performance and to influence positive workplace attitude among higher education professionals, as well as gain competitive advantage over competitors. According to Erasmus, van Wyk and Schenk (2001:526), remuneration is defined as "the financial and non-financial extrinsic rewards provided by an employer for the time, skills and effort made available by the employee for fulfilling job requirements aimed at achieving organizational objectives." Concepts such as pay, wage or salary are occasionally used as more or less having the same meaning as remuneration. Carr and Kazanowsky (1994) showed that inadequate salary was much related to employees' dissatisfaction and ultimately, unfavourable attitude towards the provision of quality services in the workplace. This demonstrates that when employees perceive that their remuneration is fair, they are most likely to experience a feeling of favorableness towards the delivery of quality services. This is because income helps individuals meet certain universal needs and therefore; income, be it financial or non-financial, is an antecedent to positive attitudinal evaluations towards service quality delivery. Based on the foregoing discourse of literature the following hypothesis is formulated for this study:

$\mathrm{H}_{1}$ : There is a positive relationship between remuneration and employee attitude.

Professional development and employee attitude: With the increasing development in technology and global competition, Eisele, Grohnert, Beausaert and Segers (2013), Mpofu and Hlatywayo (2015), Eddy, Eddy and Doughty (2015), Thomas et al. (2016) among others, appreciate the importance and need for professional development as it help institutions sustain their professional competences. Professional 
development for this study is defined as a strategic intervention designed to ensure that teaching professionals continue to strengthen competence performance (Sahinidis \& Bouris, 2008). Employee training and development aid effective functioning of any service organizations. For improvement to be possible, teaching professional need to be trained so as to improve on teaching quality service to students (Lammintakanen \& Kivinen, 2012). Training provides good administration and encourage employee to be more progressive and active at work (Johnson \& Beeh, 2014). As such, investment in employee development through training have influence employee attitude at workplace. Cooke (2012), states that, "professional development not only strengthen knowledge and skills necessary for competence performance but also values and attitudes necessary for the service orientation of a profession". Training brings about changes in awareness, motivation and confidence of attitude (Ankli \& Palliam, 2012). These changes in employee attitude allows employees go a step further to take strategic responsibility to achieving teaching objectives and goals as well as quality management (Pinnington, 2011; Beausaert, Segers, Fouarge \& Gijselaers, 2013). Staff who receive training on the emerging teaching skills/competences and technology that are required to perform well within learning environment will definitely have positive attitude to work in an effective manner and thereby influencing service delivery behavior.

H2: There is a positive relationship between professional development and employee attitude.

ICT efficiency and employee attitude: Information and communication technology (ICT) is among the developmental trends that cause significant change in global business sectors of which teaching institution are part (Laleye, 2015; Melián-González \& Bulchand-Gidumal, 2016; Johannsen, 2016). ICT is the combination of information and communication technology for knowledge sharing and collaborative use within an organization or institution in order to effectively perform or carry out both business and educational activities (Hernandez-Ortega, Serrano-Cinca \& Gomez-Mene, 2014; Granell, 2015). Computers and software such as E-mails, blog, video conferencing, social network like Blackboard teach, Facebook, you tube, internet and web tools are examples of ICT that support teaching and learning (Yassin, Salim \& Sahari, 2013). With the advance in ICT, many organizations are able to cope successfully with both internal and external competitive rivals. Chou and Shao (2014), Cohen and Olsen (2013), has recognized ICT influence on employee attitude to perform effectively. According to Laleye (2015), Otaghsara, Mohseni \& khalili (2012) \& Brewer \& Runeson (2009), ICT influence teaching attitude by bringing in new ways of teaching and learning, and thereby impacting delivery behavior towards student-centered education. Therefore teaching professionals ICT proficiency is necessary to fully contribute to knowledgeable global society and also contribute towards producing employable graduates. Thus,

H3: postulates that there is a positive relationship between ICT efficiency and employee attitude.

Employee attitude and service delivery behavior: Employee attitude may be seen as various sequences of actions (positive or negative) carried out by employees within the organization which may either strengthen or destroy a productive work environment (Welsh, Ganegoda, Arvey, Wiley \& Budd, 2012; Lee, Almanza, Jang, Nelson \& Ghiselli, 2013). The occurrence of negative behaviours can generate stress and provoke minor illnesses and even cause depression among employees (Limpanitgul, Robson, Gould-Williams \& Lertthaitrakul, 2013). The threat is that these negative behaviours are epidemic and may spread to others like the flu, which is costly to the organization's productivity and eventually takes its toll on employees' health and performance (Susskind, Borchgrevink, Kacmar \& Brymer, 2000; Dhar, 2015). Teaching professional with positive attitude is an asset in Higher Education environment because employee positive attitude influence the relationship between the determinant of good service delivery and service delivery behavior to fulfilling both clients and institution expectations (McCarthy, Reeves \& Turner, 2010; Muthanna \& Karaman, 2014). Therefore, a positive change in employee attitude can positively influence employee services delivery behavior. Positive working attitude produce positive behavior (Anand, Bisaillon, Webster \& Amor, 2015). Organisation's action to ensuring employees positive attitude is an important strategy considering the fact that positive attitude will help Higher Education achieve institutional goal and objectives towards providing employable graduates. Hence,

H4: There is a positive relationship between employee attitude and service delivery behavior. 


\section{Methodology}

A quantitative cross-sectional survey design was used to describe the service delivery behavior and its relationship with three selected determinants, namely remuneration, ICT skills and professional training. The study population was the academic workforce at one UoT in South Africa. Only those who are permanent employees and have been working there at least nine months were included in this study population. Nine months was the target inclusion period, as people tend to leave their post after one year and get permanent contracts six months after they are recruited. It was assumed after nine months one generally has an idea of one's levels of service quality delivery. As such, the inclusion/exclusion criteria determined that all those on internship and contract employees be excluded from this study.

Measurement instruments: Research scales were designed based on previous work. Proper modifications were made in order to fit the current research context and purpose. Remuneration was measured using sixitem scales adapted from Adeoye (2014). Professional development used a six-item scale measure adapted from Yan and Ming (2012). ICT efficiency used a six-item scale measure adapted from Otaghsara, Mohseni and Khalili (2014). Employee attitude was measured using a six-item scale, from McCarthy, Reeves and Turner (2010). Last but not least, service delivery behaviour was measured using a six-item scale from Adsit, London, Crom and Jones (1996). Measurement scales were configured on a five-point Likert-type scale that was anchored by 1 (strongly disagree) to 5 (strongly agree) in order to express the degree of agreement.

\section{Results}

Sample description: 250 questionnaires were distributed to different UoT higher education professionals in the Gauteng Province in South Africa. 200 questionnaires were returned of which only 195 were usable. This yielded a valid response rate of 78\%. Descriptive statistics in Table 1 show the gender, marital status, and age of higher education professional employees.

Table 1: Sample demographic characteristics

\begin{tabular}{lll}
\hline Gender & Frequency & Percentage \\
\hline Male & 78 & $40 \%$ \\
Female & 117 & $60 \%$ \\
Total & 195 & $100 \%$ \\
Age & Frequency & Percentage \\
$\leqq 30$ & 92 & $47 \%$ \\
$31-60$ & 73 & $37 \%$ \\
$\geqq 60$ & 30 & $15 \%$ \\
Total & 195 & $100 \%$ \\
Marital status & Frequency & Percentage \\
Married & 60 & $31 \%$ \\
Single & 135 & $69 \%$ \\
Total & 195 & $100 \%$ \\
\hline
\end{tabular}

As indicated in Table 1, more females participated in the study. They constructed $60 \%$ of the total population. This study shows that males only constituted $40 \%$ of the total respondents. In terms of the age groups of respondents, individuals who were less than 30 years of age were the greatest number $(47 \%)$ in the study, followed by those aged between 31 and 60 (37\%). Respondents who are married constituted 31\% of the sample while those who were single, which constituted $69 \%$ of the sample.

Psychometric Properties of the Measurement Scale: Psychometric properties of the measurement scale are reported in Table 2, which presents the research constructs, Cronbach alpha test, composite reliability (CR), Average variance extracted (AVE) and item loadings. 
Table 2: Measurement Accuracy Assessment and Descriptive Statistics

\begin{tabular}{|c|c|c|c|c|c|c|c|}
\hline \multirow[t]{2}{*}{ Research constructs } & \multicolumn{2}{|c|}{$\begin{array}{l}\text { Descriptive } \\
\text { statistics* }\end{array}$} & \multicolumn{2}{|c|}{ Cronbach's test } & \multirow[t]{2}{*}{ C.R. } & \multirow[t]{2}{*}{$\overline{\text { AVE }}$} & \multirow[t]{2}{*}{$\begin{array}{l}\text { Item } \\
\text { Loadings }\end{array}$} \\
\hline & Mean & SD & $\begin{array}{l}\text { Item- } \\
\text { total }\end{array}$ & $\begin{array}{l}\alpha \\
\text { Value }\end{array}$ & & & \\
\hline \multicolumn{8}{|l|}{ Remuneration (RM) } \\
\hline RM 1 & & & 0.503 & 0.795 & 0.793 & 0.609 & 0.559 \\
\hline RM 2 & & & 0.623 & & & & 0.673 \\
\hline RM 3 & 2.62 & 1.700 & 0.719 & & & & 0.730 \\
\hline RM 4 & & & 0.601 & & & & 0.618 \\
\hline RM 5 & & & 0.699 & & & & 0.705 \\
\hline RM6 & & & 0.622 & & & & 0.658 \\
\hline \multicolumn{8}{|c|}{ Professional Development (PD) } \\
\hline PD 1 & & & 0.511 & & & & 0.564 \\
\hline PD 2 & & & 0.765 & & & & 0.802 \\
\hline PD 3 & 3.15 & 1.007 & 0.733 & 0.830 & 0.830 & 0.700 & 0.762 \\
\hline PD 4 & & & 0.810 & & & & 0.852 \\
\hline PD 5 & & & 0.555 & & & & 0.568 \\
\hline PD 6 & & & 0.622 & & & & 0.721 \\
\hline \multicolumn{8}{|l|}{ ICT Efficiency (IE) } \\
\hline IE 1 & & & 0.683 & & & & 0.716 \\
\hline IE 2 & & & 0.670 & & & & 0.727 \\
\hline IE 3 & 3.02 & 1.355 & 0.591 & 0.785 & 0.784 & 0.600 & 0.654 \\
\hline IE 4 & & & 0.601 & & & & 0.628 \\
\hline IE 5 & & & 0.615 & & & & 0.672 \\
\hline IE6 & & & 0.700 & & & & 0.793 \\
\hline \multicolumn{8}{|l|}{ Employee Attitude (EA) } \\
\hline EA 1 & & & 0.634 & & & & 0.664 \\
\hline EA 2 & & & 0.625 & & & & 0.652 \\
\hline EA 3 & 2.22 & 1.733 & 0.596 & 0.799 & 0.799 & 0.605 & 0.622 \\
\hline EA 4 & & & 0.705 & & & & 0.714 \\
\hline EA 5 & & & 0.781 & & & & 0.783 \\
\hline EA 6 & & & 0.741 & & & & 0.750 \\
\hline \multicolumn{8}{|c|}{ Service Delivery Behavior (SB) } \\
\hline SB 1 & & & 0.723 & & & & 0.793 \\
\hline SB 2 & & & 0.801 & & & & 0.812 \\
\hline SB 3 & 3.15 & 1.007 & 0.733 & 0.850 & 0.850 & 0.700 & 0.741 \\
\hline SB 4 & & & 0.811 & & & & 0.849 \\
\hline SB 5 & & & 0.742 & & & & 0.755 \\
\hline SB 6 & & & 0.551 & & & & 0.557 \\
\hline
\end{tabular}

The lowest item to total loading observed was RM 1 with 0.503 and the highest was SB4 with 0.811 . The lowest factor loading observed was SB 6 with 0.557 and the highest is SB 4 with 0.849 . This shows that the measurement instruments are valid. The lowest Cronbach alpha was 0.785 and the highest was 0.850 , which shows that the constructs were internally consistent or reliable and explained more that $60 \%$ of the variance. All composite reliability values were above the recommended minimum of 0.7 (Bagozzi \& Yi, 1988), which further attests to the reliability of the measurement instrument used in the study. One of the methods used to 
ascertain the discriminant validity of the research constructs was the evaluation of whether the correlations among latent constructs were less than 0.60 . These results are reported in Table 3.

Table 3: Inter-Construct Correlation Matrix

\begin{tabular}{|c|c|c|c|c|c|}
\hline Variables & RM & PD & IE & EA & SB \\
\hline RM & 0.543 & & & & \\
\hline PD & 0.500 & 0.598 & & & \\
\hline IE & 0.493 & 0.561 & 0.430 & & \\
\hline EA & 0.470 & 0.499 & 0.442 & 0.505 & \\
\hline SB & 0.300 & 0.370 & 0.307 & 0.466 & 0.588 \\
\hline $\begin{array}{l}\text { RM=Remuneration; } \\
\text { Service Delivery beho }\end{array}$ & $\begin{array}{l}P D=\text { Professional } \\
\text { avior }\end{array}$ & Development; & IE=ICT efficiency; & $E A=$ Employee & Attitude; $S B=$ \\
\hline
\end{tabular}

A correlation value between constructs of less than 0.60 is recommended in the empirical literature to confirm the existence of discriminant validity (Bagozzi \& Yi, 1988). As can be observed from Table 3, all the correlations were below the acceptable level of 0.60 . The diagonal values in bold are the Shared Variances (SV) for the respective research constructs. The Shared Variance is expected to be greater than the correlation coefficients of the corresponding research constructs. Drawing from Table 2 and 3 above, the results further confirm the existence of discriminant validity. To ascertain convergent validity, the factor loadings were considered in order to assess if they were above the recommended minimum value of 0.5 (Nunnally \& Bernstein, 1994). The factor loadings for scale items (Table 2) were above the recommended 0.5, which indicated that the instruments were valid and converging well on the constructs that they were expected to measure.

Path Modelling Results: After confirming the reliability and validity of the measurement instruments (reported in Table 2), the study proceeded to test the proposed hypotheses. In total, there are four hypotheses that are tested. In the path model, Remuneration (RM); Professional Development (PD) and ICT efficiency (IE) are the predictor variables. Employees attitude (EA) is the mediator and Service delivery behaviour (SB) is the outcome/dependent variable. Figure 2 provides the proposed hypotheses and the respective path coefficients. The same results of the path coefficients are tabulated in Table 2 depicting the Item to Total correlations, Average variance extracted (AVE), Composite Reliability (CR) and Factor Loadings.

Path model results and factor loadings: Below is Figure 2, indicating the path modelling results and as well as the item loadings for the research constructs. In the figure, RM stand for Remuneration; PD is the acronym for Professional Development; IE stand for ICT Efficiency; EA is the acronym for Employee Attitude and SB stand for Service Delivery Behaviour

Table 4: Results of structural equation model analysis

\begin{tabular}{|c|c|c|c|c|}
\hline Path & Hypothesis & $\begin{array}{l}\text { Path coefficients } \\
(\beta)\end{array}$ & T-Statistics & $\begin{array}{l}\text { Decision on } \\
\text { Hypotheses }\end{array}$ \\
\hline $\begin{array}{l}\text { Remuneration } \quad(\mathrm{RM}) \quad \rightarrow \text { Employee } \\
\text { Attitude (EA) }\end{array}$ & $\mathrm{H} 1$ & $0.137^{a}$ & 2.483 & $\begin{array}{l}\text { Accept/ } \\
\text { Significant }\end{array}$ \\
\hline $\begin{array}{l}\text { Professional Development } \\
\rightarrow \text { Employee Attitude (EA) }\end{array}$ & $\mathrm{H} 2$ & $0.392^{\mathrm{a}}$ & 3.906 & $\begin{array}{l}\text { Accept/ } \\
\text { Significant }\end{array}$ \\
\hline $\begin{array}{l}\text { ICT Efficiency } \\
\text { Attitude (EA) }\end{array}$ & H3 & $0.336^{\mathrm{a}}$ & 3.143 & $\begin{array}{l}\text { Accept/ } \\
\text { Significant }\end{array}$ \\
\hline $\begin{array}{l}\text { Employee Attitude (EA) } \rightarrow \text { Service } \\
\text { Delivery Behaviour (SB) }\end{array}$ & $\mathrm{H} 4$ & $0.731^{\mathrm{a}}$ & 11.989 & $\begin{array}{l}\text { Accept/ } \\
\text { Significant }\end{array}$ \\
\hline
\end{tabular}

aSignificance Level $\mathrm{p}<.10$; Significance Level $\mathrm{p}<.05$; 'Significance Level $\mathrm{p}<.01$. 
Figure 2: Path Modelling and Factor Loading Results

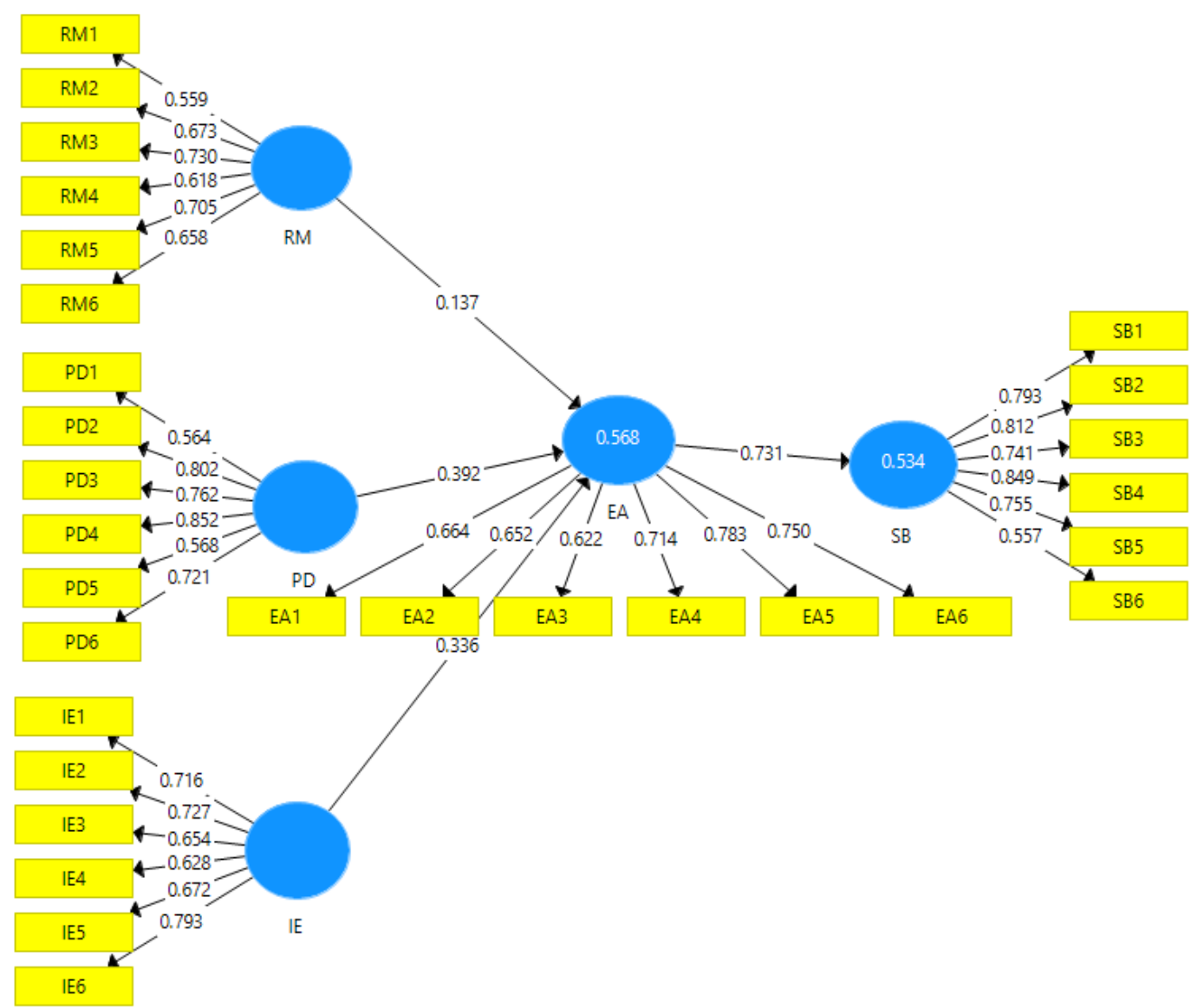

Table 4 presents the four hypothesised relationships, path coefficients, the t-statistics and the decision criteria. The value of the t-statistic indicates whether the relationship is significant or not. A significant relationship is expected to have a t-statistics that is above 2. Drawing from the results provided in Table 4, four of the hypothesised relationships (H1, H2, H3 and H4) were statistically significant.

Discussion: The purpose of this paper was to examine the influence of remuneration, professional development and ICT efficiency on employee attitude and service delivery behaviour in one UoT in South Africa. The first hypothesis stated that remuneration of employees has a positive influence on employee attitude towards work. In this study, this hypothesis was supported. It can be observed in Figure 2 and Table 4 that perceived remuneration exerted a positive influence $(r=0.137)$ and was statistically significant $(\mathrm{t}=2.483)$ in predicting employee attitude towards work. This result implies that remuneration directly influence employee attitude towards work in a positive and significant fashion. The higher the level of remuneration, the higher the level of positive attitude towards work. The second hypothesis suggested that professional development a positive influence on employee attitude towards work. This hypothesis was supported in this study. Figure 1 and Table 4, indicate that professional development H2 was supported. Professional development exerted a positive influence $(r=0.392)$ on employee attitude towards work and was statistically significant $(\mathrm{t}=3.906)$. This result denotes that professional development is positively and significantly related to employee attitude towards work. Thus higher levels of professional development will lead to higher levels of employee attitude towards work.

The third hypothesis, which advanced that ICT efficiency exerts a positive influence on employee attitude towards work was supported and accepted in this study. It is reported in Figure 1 and Table 4 that H3 
employee ICT efficiency exerts a positive $(r=0.336)$ influence on employee attitude towards work and that this influence is statistically significant $(t=3.143)$. This result suggests that employee ICT efficiency has a direct positive effect on employee attitude towards work. Thus, the more effective the ICT efficiency, the greater the positive employee attitude towards work. The final hypothesis postulated that employee attitude towards workexerts a positive influence on service delivery behaviour of employees. In this study, this hypothesis was supported and accepted. As can be deducted from Figure 1and Table 4, employee attitude towards work exerted a positive and significant influence $(r=0.731 ; \mathrm{t}=11.989)$ on service delivery behaviour of employees. This result depicts that employee attitude towards work is associated with higher service delivery behaviour of employees. Employees attitude towards work $(r=0.731)$ emerged as the highest scoring construct amongst the three factors influencing service delivery behaviour of employees. Perhaps, this result could be attributed to the fact that most higher education professions perform better and service delivery behaviour is at its peak when they have a good attitude towards work. Thus, in order to enhance good service delivery behaviour, greater emphasis should be placed on employee attitude towards work.

Limitations and Future Research Direction: A number of limitations were observed during this research. First, the study was restricted to five factors only; namely Remuneration, Professional Development, ICT Efficiency, Employee Attitude and Service Delivery Behavior. Future research could also include the perceptions of students as well. This could provide a basis for comparing the views of both students and employees. Second, the results are based on a small sample of 195 respondents, which makes it difficult to generalise the results to other contexts of higher education institution, UoTs in particular. Future studies could make use of amplified sample sizes in order to get views that are more representative. Since this study used a quantitative approach, future studies could also use a mixed method approach so that in depth views of higher education professionals can also be captured.

\section{Conclusion and Managerial Implications}

The study validates those factors such as rremuneration, professional Development and ICT efficiencyare instrumental stimulating employee attitude and service delivery behavior of employees. The study further validates that employee attitude towards work is good when the remuneration is good, professional development and ICT efficiency. Also employee attitude leads to more service delivery behaviour of employees. The study also underwrites a new direction in the research on consumer behaviour by opening up a discussion on the importance of marketing practices in the development and improvement of service delivery behaviours in one UoTs in South Africa. The study has both theoretical and managerial implications. Theoretically, this study makes a noteworthy progression in marketing theory by methodically examining the interplay between rremuneration; professional development and ICT efficiencyare instrumental stimulating employee attitude and service delivery behavior of employees. In this manner, the study is an important contributor to the existing literature on this subject. The study also underwrites a new direction in the research on consumer behaviour by opening up a discussion on the importance of marketing practices in the development and improvement of service delivery behaviours in one UoTs in South Africa.

On the practical front, since remuneration, professional development and ICT efficiency were exerted a positive influence on employee attitude towards work and service delivery behaviour, improvements in each of these three factors could stimulate higher service delivery behaviours in one of the UoTs in South Africa. Remuneration can be improved by paying salaries above poverty datum line and equity issues should be addressed. With regards to Professional development, more staff should be sent for training either in house or out of the company. ICT efficient there is need adopt new technologies of making work easier like the blackboard training. Employee attitudes at work can be improved through learning the benefits of organisational citizenship behaviours and avoiding organisational politics. Free Wi-Fi could also be made available at the whole campus for efficacy reasons. Seeing the importance as well as the significant valueadding for money emanating from service delivery behaviour, it is further recommended that a climate of continuous staff development that support and allow a gradual improvement of employee competences is important to service delivery excellent among UoT teaching professionals. Further study on the subject matter could be extended to other service organisation apart from UoT and possibly to traditional university in South Africa. 


\section{References}

Adams, J. S. (1963). Toward an understanding of inequality. Journal of Abnormal and Social Psychology, 67, 422-436.

Adams, J. S. (1965). Inequity in social exchange. In L Berkowitz (Ed). Advances in experimental social psychology, 267-299. New York: Academic Press.

Adeoye, A. O. (2014). The influence of compensation management on employee's leadership role in insurance sector: Nigeria Experience. Mediterranean Journal of Social Sciences, 5(27), 342-352.

Adsit, D. J., London, M., Crom, S. \& Jones, D. (1996). Relationships between employee attitudes, customer satisfaction and departmental performance. Journal of Management Development, 15 (1), 62-75.

Aguinis, H., Joo, H. \& Gottfredson, R. K. (2013). What monetary rewards can and cannot do: How to show employees the money. Business Horizon, 56, 241-249.

Almar, M. W. (2005). Equity sensitivity and negotiation behaviors: A look at Mexican exporters. Academy of Management Journal, 4(3), 1-16.

Anand, C. K., Bisaillon, V., Webster, A. \& Amor, B. (2015).Integration of sustainable development in higher education - a regional initiative in Quebec (Canada). Journal of Cleaner Production, 108, 916-923.

Andrzejewski, S. A. \& Mooney, E. C. (2016). Service with a smile: Does the type of smile matter? Journal of Retailing and Consumer Services, 29, 135-141.

Ang S., Van Dyne, L. \& Begley, T. M. (2003). The employment relationships of foreign workers versus local employees: a field study of organizational justice, job satisfaction, performance, and OCB. Journal of Organizational Behavior, 24(5), 561-583.

Anitha, J. (2014). Determinants of employee engagement and their impact on employee performance. International Journal of Productivity and Performance Management, 63(3), 308-323.

Ankli, R. E. \& Palliam, R. (2012). Enabling a motivated workforce: exploring the sources of motivation. Development and Learning in Organizations: An International Journal, 26(2), 7-1.

Antoncic, J. A. \& Antoncic, B. (2011). Employee satisfaction, intrapreneurship and firm growth: a model. Industrial Management \& Data Systems, 111(4), 589-607.

Bagozzi, R. P. \& Yi, Y. (1988). On the Evaluation of Structural Equation Models. Journal of Academy of Marketing Science, 16(1), 74-94.

Bartel, A. P., Freeman, R. B., Ichniowski, C. \& Kleiner, M. M. (2011). Can a workplace have an attitude problem? Workplace effects on employee attitudes and organizational performance. Labor Economics, 18(4), 411-423.

Beausaert, S., Segers, M., Fouarge, D. \& Gijselaers, W. (2013). Effect of using a personal development plan on learning and development. Journal of Workplace Learning, 25(3), 45-158.

Bienstock, C. C., DeMoranville, C. W. \& Smith, R. K. (2003). Organizational citizenship behavior and service quality. Journal of Service Marketing, 17(4), 357-378.

Blašková, M. \& Blaško, R. (2014). Motivating university teachers through prism of their remuneration. Procedia - Social and Behavioral Sciences, 110, 595-606.

Brewer, G. \& Runeson, G. (2009). Innovation and attitude: Mapping the profile of ICT decision-makers in architectural, engineering and construction firms. International Journal of Managing Projects in Business, 2(4), 599-610.

Carraher, S. M. (2011). Turnover prediction using attitudes towards benefits, pay, and pay satisfaction among employees and entrepreneurs in Estonia, Latvia, and Lithuania. Baltic Journal of Management, 6(1), 25-52.

Chaiprasit, K. \& Santidhirakul, O. (2011).Happiness at Work of Employees in Small and Medium-sized Enterprises, Thailand. Procedia - Social and Behavioral Sciences, 25, 189-200.

Chou, Y. C. \& Shao, B. B. M. (2014).Total factor productivity growth in information technology services industries: A multi-theoretical perspective. Decision Support Systems, 62, 106-118.

Chumg, H. F., Seaton, J., Cook, L. \& Ding, W. Y. (2016). Factors affecting employees' knowledge-sharing behavior in the virtual organization from the perspectives of well-being and organizational behavior. Computers in Human Behavior, 64, 432-448.

Cohen, J. F. \& Olsen, k. (2013). The impacts of complementary information technology resources on the service-profit chain and competitive performance of South African hospitality firms. International Journal of Hospitality Management, 34, 245-254. 
Cooke, N. A. (2012). Professional development 2.0 for librarians: developing an online personal learning network (PLN). Library Hi Tech News, 29(3), 1-9.

Davies, D., Taylor, R. \& Savery, L. (2001). The role of appraisal, remuneration and training in improving staff relations in the Western Australian accommodation industry: a comparative study. Journal of European Industrial Training, 25(7), 366 - 373.

Dhar, R. L. (2015). Service quality and the training of employees: The mediating role of organizational commitment. Tourism Management, 46, 419-430.

Doherty, N. F., Shakur, M. \& Ellis-Chadwick, F. (2015). The role of e-service quality management in the delivery business value. Journal of Retailing and Consumer Services, 27, 52-62.

Dorasamy, N. (2010). Enhancing an ethical culture through purpose-directed leadership for improved public service deliver: a case for South Africa. Africa Journal of Business Management, 4(1), 056-064.

Echchakoui, S. (2016). Relationship between sales force reputation and customer behavior: Role of experiential value added by sales force. Journal of Retailing and Consumer Services, 28, 54-66.

Eddy, A., Eddy, D. \& Doughty, J. (2015). Evidencing Continual Professional Development: Maximizing Impact and Informing Career Planning. Journal of Medical Imaging and Radiation Sciences, 46(4), 361-364.

Eisele, L., Grohnert, T., Beausaert, S. \& Segers, M. (2013). Employee motivation for personal development plan effectiveness. European Journal of Training and Development, 37(6), 527-543.

Granell, X. (2015). A strategic approach to adopt ICT: from using information and communication technology to making use of information and technology to communicate. Multilingual Information Management, $1,45-59$.

Hernandez-Ortega, B., Serrano-Cinca, C. \& Gomez-Mene, F. (2014). The firm's continuance intentions to use inter-organizational ICTs: The influence of contingency factors and perceptions. Information and Management, 51,747-761.

Holtom, B. C. \& Burch, T. C. (2016). A model of turnover-based disruption in customer services. Human Resource Management Review, 26, 25-26.

Hon, A. H. Y. (2012). When competency-based pay relates to creative performance: The moderating role of employee psychological need. International Journal of Hospitality Management, 31, 130-138.

Jain, A. K. (2015). Volunteerism and organizational culture. Cross Cultural Management, 22(1), 116-144.

Johannsen, C. G. (2016). From Clients to Participants - How Information Technology Impacts Relationships between Professionals and Users. Digital Information Strategies, 1, 157-166.

Johnson, V. A. \& Beeh, T. A. (2014). Making use of professional development: Employee interests and motivational goal orientations. Journal of Vocational Behavior, 84, 99-108.

Kinicki, A. \& Kreitner, R. (2008). Organisational Behaviour. Key concepts, skills and best practices. McGraw Hill, New York.

Laleye, A. M. (2015). Educational Technology for Effective Service Delivery in Educational Training and Research in Nigeria. Procedia - Social and Behavioral Sciences, 176, 398-404.

Lammintakanen, J. \& Kivinen, T. (2012). Continuing professional development in nursing: does age matter? Journal of Workplace Learning, 24(1), 34-47.

Lee, J. E., Almanza, B. A., Jang, S. S., Nelson, D. C. \& Ghiselli, R. F. (2013). Does transformational leadership style influence employees' attitudes toward food safety practices? International Journal of Hospitality Management, 33, 282-293.

Limpanitgul, T., Robson, M. J., Gould-Williams, J. \& Lertthaitrakul, W. (2013). Effects of co-worker support and customer cooperation on service employee attitudes and behavior: Empirical evidence from the airline industry. Journal of Hospitality and Tourism Management, 20, 23-33.

Lin, J. S. C. \& Lin, C. Y. (2011). What makes service employees and customers smile? Journal of Service Management, 22(2), 183-201.

Liu, C. H. S. \& Lee, T. (2016). Service quality and price perception of service: Influence on word-of-mouth and revisit intention. Journal of Air Transport Management, 52, 42-54.

Lues, L. (2007). Service delivery and ethical conduct in the public service: the missing links. Koers, 72(2), 219238.

McCarthy, D., Reeves. E. \& Turner, T. (2010). Can employee share-ownership improve employee attitudes and behavior? Employee Relations, 32(4), 382-395.

Mechinda, P. \& Patterson, P. G. (2011). The impact of service climate and service provider personality on employees' customer-oriented behavior in a high contact setting. Journal of Service Marketing, 25(2), 101-113. 
Melián-González, S. \& Bulchand-Gidumal, J. (2016). A model that connects information technology and hotel performance. Tourism Management, 53, 30-37.

Mpofu, M. \& Hlatywayo, C. K. (2015). Training and development as a tool for improving basic service delivery; the case of a selected municipality. Journal of Economics, Finance and Administrative Science, 20, 133136.

Muthanna, A. \& Karaman, A. C. (2014). Higher education challenges in Yemen: Discourses on English teacher education. International Journal of Educational Development, 37, 40-47

Nisiforou, O. A., Poullis, S. \& Charalambides, A. G. (2012). Behavior, attitudes and opinion of large enterprise employees with regard to their energy usage habits and adoption of energy saving measures. Energy and Buildings, 55, 299-311.

Nunnally, J. \& Bernstein, I. (1994). Psychometric theory. (3 $3^{\text {rd }}$ Edition). New York: McGraw-Hill.

Otaghsara, M. K., Mohseni, A. \& khalili, M. (2014). The role of ICT in-service training of employees of government Organization: (Case Study: Institute of Water and Power Unit, Mazandaran). Procedia Social and Behavioral Sciences, 47, 1985-1990.

Pinnington, A. H. (2011). Competence development and career advancement in professional service firms. Personnel Review, 40(4), 443-465.

Pugh, S. D. \& Subramony, M. (2016). Taking services seriously: New directions in services management theory and research. Human Resource Management Review, 26, 1-3

Ratanavaraha, V., Jomnonkwao, S., Khampirat, B., Watthanaklang, D. \& Iamtrakul P. (2016).The complex relationship between school policy, service quality, satisfaction, and loyalty for educational tour bus services: A multilevel modeling approach. Transport Policy, 45, 116-126.

Ruth, D., Brush, T. H. \& Ryu, W. (2015). The use of information technology in the provision of HR compensation services and its effect on outsourcing and centralization. Journal of Purchasing and Supply Management, 21(1), 25-37.

Sá, F., Rocha, A. \& Cota, M. P. (2016). Potential dimensions for a local e-Government services quality Model. Telematics and Informatics, 33, 270-276.

Sahinidis, A. G. \& Bouris, J. (2008). Employee perceived training effectiveness relationship to employee attitudes. Journal of European Industrial Training, 32(1), 63-76.

Sibanda, M. M. (2012). Monitoring customer-focused quality service delivery in local government: conceptual issues and perspectives for consideration. Africa's Public Service Delivery \& Performance Review (APSDPR), 1, 1-20.

Steinbeis, N. \& Singer, T. (2013). The effects of social comparison on social emotions and -behavior during childhood: The ontogeny of envy and Schadenfreude predicts developmental changes in equityrelated decisions. Journal of Experimental Child Psychology. doi: 10.1016/j.jecp.2012.11.009.

Susskind, A. M., Borchgrevink, C. P., Kacmar, K. M. \& Brymer, R. A. (2000). Customer service employees' behavioral intentions and attitudes: an examination of construct validity and a path model. International Journal of Hospitality Management, 19, 53-77.

Thomas, T., Passfield, L., Coulton, S. \& Crone, D. (2016). Effectiveness of a tailored training program in behavior change counseling for community pharmacists: A pilot study. Patient Education and Counseling, 99(1), 132-138.

Verbich, D. \& Ahmed, E. G. (2016). The pursuit of satisfaction: Variation in satisfaction with bus transit service among riders with encumbrances and riders with disabilities using a large-scale survey from London, UK. Transport Policy, 47, 64-71

Wahab, O. A., Bentahar, J., Otrok, H. \& Mourad, A. (2016). A Stackelberg game for distributed formation of business-driven services communities. Expert Systems with Applications, 45, 359-372.

Wang, Q., Zhao, X \& Voss, C. (2016). Customer orientation and innovation: A comparative study of manufacturing and service firms. International Journal of Production Economics, 171, 221-230.

Wells, P. J. (2015). Executive remuneration: regulatory reforms in UK company law. International Journal of Law and Management, 57(4), 300-339.

Welsh, E. T., Ganegoda, D. B., Arvey, R. D., Wiley, J. W. \& Budd, J. W. (2012). Is there fire? Executive compensation and employee attitudes. Personnel Review, 41(3), 260-282.

Wen, J., Li, Y. \& Hon, P. (2016). Customer mistreatment behavior and hotel employee organizational citizenship behavior: the mediating role of perceived organizational support. Nankai Business Review International, 7(3), 322-344. 
Yan, L. C. \& Ming, L. W. (2014). An investigation of employee attitudes towards training effectiveness. Mediterranean Journal of Social Sciences, 15(5), 810-824.

Zalewska, A. (2014). Gentlemen do not talk about money: Remuneration dispersion and firm performance relationship on British boards. Journal of Empirical Finance, 27, 40-57.

Zayas-Ortiz, M., Rosario, E., Marquez, E. \& Gruneiro, P. C. (2015). Relationship between organizational commitments and organizational citizenship behavior in a sample of private banking employees. International Journal of Sociology \& Social Policy, 35(1/2), 91-106. 